\section{Health, environmental, and economic costs from the use of a stabilized diesel/ethanol mixture in the city of São Paulo, Brazil}

\author{
Avaliação dos custos econômicos, ambientais \\ e de saúde pública devido ao uso de mistura \\ diesel/etanol estabilizada por um aditivo \\ comercial na cidade de São Paulo, Brasil
}

Simone Georges El Khouri Miraglia 1,2

\section{Introduction}

In Greater Metropolitan São Paulo, Brazil, fossil fuel combustion in the transportation system is a major cause of outdoor air pollution. Air quality improvement requires additional policies and technological upgrades in fuels and vehicle engines. The current study thus simulated the environmental and social impacts resulting from the use of a stabilized diesel/ethanol mixture in the bus and truck fleet in Greater Metropolitan São Paulo. The evaluation showed reductions in air pollutants, mainly $P M_{10}$, which would help avert a number of disease events and deaths, as estimated through dose-response functions of epidemiological studies on respiratory and cardiovascular diseases. Valuation of the impacts using an environmental cost-benefit analysis considered operational installation, job generation, potential carbon credits, and health costs, with an overall positive balance of US\$ 2.851 million. Adding the estimated qualitative benefits to the quantitative ones, the project's benefits far outweigh the measured costs. Greater Metropolitan São Paulo would benefit from any form of biodiesel use, producing environmental, health and socioeconomic gains, the three pillars of sustainability.

Environmental Impact; Vehicle Emissions; Air Pollutants
Urban air pollution has become an important environmental issue, especially affecting children and the elderly. Increased acute and chronic diseases have been associated with automotive fleet-generated air pollutants. In Greater Metropolitan São Paulo, Brazil, outdoor air pollution is largely and increasingly a consequence of fossil fuel combustion in the transportation system. In the last 50 years the automotive fleet has increased from one car per 50 inhabitants to approximately one car per two inhabitants 1 . Additionally, expansion of commercial and industrial activities has attracted a large fleet of trucks that operate in and across the cities comprising the Metropolitan Area. Meanwhile, the bus fleet has increased to nearly 43,000 vehicles. Most of the trucks and buses run on fossil fuels, using lowtech engines that are more than ten years old, thereby increasing pollutant emissions.

PROCONVE, a national program to improve engine operations and reduce emissions, was launched in the late 1980s and led to overall reductions of primary air pollutant levels. However, on-going expansion of the automotive fleet may reduce the program's effectiveness. Hence, additional policies and technological upgrades in fuels and vehicle engines are required to improve air quality in Greater Metropolitan São Paulo and elsewhere. 
The current study thus simulated the environmental and social impacts of using an additive to provide a stabilized ethanol/diesel blend in the bus and truck fleet in Greater Metropolitan São Paulo. This fuel technology substantially reduces harmful emissions without sacrificing engine power or performance.

The study was conducted to estimate the costs and benefits of this additive in truck and bus fleets in Greater Metropolitan São Paulo, focusing on its health impacts and other associated social and environmental issues.

\section{Material and methods}

Environmental valuation is extremely useful for estimating economic and environmental project feasibility and conducting environmental impact assessment studies and setting environmental fines and environmental compensation plans. Environmental valuation can also be used to evaluate the introduction of new technologies or materials with potential environmental impacts.

Air quality is one of the environmental issues with the greatest impact on the city of São Paulo. Measures to reduce air pollutant emissions have been encouraged, since they produce evident environmental and social gains. Since air pollution in São Paulo is due largely to vehicle emissions, and based on the key contribution of diesel vehicle emissions to regulated pollutants $\left(\mathrm{PM}_{10}, \mathrm{CO}\right.$, $\mathrm{HC}, \mathrm{NO}_{\mathrm{x}}$ ), the dilution of diesel fuel with ethanol should be expected to help improve the city's air quality.

Natural resources involve a wide range of externalities, so conventional analytical methods are unable to deal adequately with their depletion or degradation. In order to correct this problem using a broader concept of the economic value of environmental resources, environmental cost-benefit analysis estimates the total economic value (TEV) 2:

$\mathrm{TEV}=$ value of use $(\mathrm{VU})+$ option value $(\mathrm{OV})+$ existence value (EV).

Value of use (VU) represents the value people attribute to the use of environmental resources. VU has two components: DVU (direct value of use) and IVU (indirect value of use). DVU computes the internalized benefit of an individual through any productive activity or direct consumption of the resource. IVU considers the benefit of the resource derived from ecosystem functions such as the protection of water resources derived from forest conservation. The option value $(\mathrm{OV})$ refers to an option for a future use - direct or indirect - instead of the present use as considered in the VU.
Existence value (EV) is characterized as a nonuse value. It is difficult to conceptualize, since it represents a value attributed to the existence of the environment, independently of its present or future use. It refers to the value people attribute to certain environmental resources like forests and animals threatened with extinction, even if people do not intend to use or enjoy them.

The task of economically valuing a natural resource entails identifying monetary values that reflect such externalities. In other words, the economic value should represent the extent to which societal well-being improves or worsens due to changes in the use or appropriation of environmental resources over time.

\section{Methods of natural resource valuation}

Revealed preference methods $2,3,4$ use the complementary or substitute private goods and services market to measure the resource's VU. A limitation of such methods is their incapacity to evaluate all the additional components of a natural resource's economic value, i.e., the values of non-use, option, and existence. Even so, they can provide an approximation of the economic value to be measured.

The averting behavior method (ABM) is especially suited for valuing natural qualities. This is done by looking at expenditures made to avert or mitigate negative effects from the reduction of a natural quality. ABM relies on the assumption that people perceive the negative effects of environmental deterioration on their welfare and that they are capable of adapting their behavior to avert or reduce such effects. It considers that the loss of the natural resource is worth at least the expenditure involved in its recovery.

Estimates of the averting expenditures incurred by third parties (expenses with cleaning, medicines, health treatment, property damages, etc.) are already included in the indemnity imposed on the polluter.

\section{Economic costs}

The economic cost estimate for introducing the additive used the estimate of DVU through the $\mathrm{ABM}$ of the necessary measures for retrofitting the fleet's refueling tanks, personal training, and the cost of the ethanol-blended diesel fuel compared to regular diesel.

\section{Economic benefits}

The additive's economic benefits include improved vehicle maintenance, extended oil drain intervals, and reduced engine residues. However, 
since the data to measure these gains in the fleet were not available, these benefits were assessed in qualitative terms.

\section{Economic and social benefits (from sugarcane cultivation)}

Some benefits were estimated in qualitative terms, specifically sustainable development, including use of renewable energy and an unskilled workforce with limited job opportunities.

Other potential benefits were: job generation (DVU), decreased dependence on imports (DVU), and the possibility of obtaining carbon credits (IVU). Thus, job generation was evaluated (directly and indirectly) based on the additional ethanol consumption. The same procedure was used to estimate the potential carbon credits from additional ethanol production.

\section{Health benefits}

Health gains due to air quality improvement after introduction of the additive were estimated by calculating the DVU through $\mathrm{ABM}$, estimating expenses with hospital admissions, work absenteeism, and value of statistical life (VOSL).

\section{Main data sources}

\section{Air pollution scenario}

The present study used data from diesel engine performance tests approved by the California Air Resources Board (California Environmental Protection Agency) (Table 1) and an analysis of the Laboratório de Poluição Atmosférica Experimental, Faculdade de Medicina, Universidade de São Paulo (LPAE-FMUSP; Laboratory of Experimental Air Pollution at the School of Medicine, University of São Paulo). The study estimated the potential reduction in principal atmospheric pollutants by diesel engines using the additive (Table 2) and the total health effects abatement (Table 3) in Greater Metropolitan São Paulo.

Sources of atmospheric pollutants in Greater Metropolitan São Paulo were identified by Companhia de Tecnologia de Saneamento Ambiental (CETESB; Environmental Sanitation Technology Company), the official environmental agency responsible for the air monitoring system and environmental policy management in São Paulo State.

Table 2 shows the calculations for the target additive application in terms of air pollutant reduction, considering diesel sources only and overall sources of each pollutant according to the additive supplier.

\section{Epidemiological analysis}

An epidemiological study was conducted to determine the mitigation of harmful health effects due to use of the additive in the bus and truck fleet in São Paulo. The study was based on previous results from epidemiological studies conducted at LPAE-FMUSP, basically showing an association between morbidity-mortality and air pollution in São Paulo. Estimates of the health effects averted by the abatement measures are based on concentration-response (C-R) coefficients obtained from epidemiological studies.

Table 3 presents the expected reduction in air pollutant concentrations in the scenario with the implementation of the stabilized ethanol/diesel blend and the number of disease events and deaths attributable to air pollution exposure. For each outcome, a pollutant was adopted that presented the largest effect. Because changes in air pollutant concentrations are related to the same scenario, it was assumed that the total number of averted events in the blend use scenario compared to the real scenario was the sum of all disease events and deaths. In general, implementation of an ethanol/diesel blend can be expected to reduce adverse health events by 0.7 to $3.4 \%$.

Table 1

Reduction (\%) of main air pollutants with the use of the target diesel additive rather than diese EPA no. 2.

\begin{tabular}{lcccc}
\hline & $\mathrm{PM}_{10}$ & NO $_{\mathbf{x}}$ & CO & Smoke \\
\hline Minimum & 20.0 & 1.6 & 12.0 & 50.0 \\
Maximum & 31.0 & 3.0 & 23.0 & 70.0
\end{tabular}

$\mathrm{PM}_{10}$ : particulate matter; $\mathrm{NO}_{\mathrm{x}}$ : nitrogen oxides; $\mathrm{CO}$ : carbon monoxide.

Table 2

Reduction (\%) in atmospheric pollutants with the use of the stabilized blend rather than regular diesel available in Greater Metropolitan São Paulo, Brazil.

\begin{tabular}{lccc}
\hline Sources & CO & $\mathrm{NO}_{\mathbf{x}}$ & $\mathrm{PM}_{10}$ \\
\hline Diesel only & 6.47 & 0.86 & 10.79 \\
All sources & 1.67 & 0.70 & 3.32 \\
\hline
\end{tabular}

$\mathrm{CO}$ : carbon monoxide; $\mathrm{NO}_{\mathrm{x}}$ : nitrogen oxides; $\mathrm{PM}_{10}$ : particulate matter. 
Estimated morbidity and mortality in Greater Metropolitan São Paulo, Brazil, in the two scenarios analyzed in the study.

\begin{tabular}{|c|c|c|c|c|c|}
\hline \multirow[t]{3}{*}{ Outcomes } & \multicolumn{4}{|c|}{ Scenarios } & \multirow{3}{*}{$\begin{array}{l}\text { Avertable events } \\
\left(\% \text { reduction }{ }^{*}\right)\end{array}$} \\
\hline & \multicolumn{2}{|c|}{ Pollutants * } & \multicolumn{2}{|c|}{ Attributable events } & \\
\hline & Real & Blend & Real & Blend & \\
\hline PRHA (PM 10$)$ & 51.50 & 49.80 & 6,712 & 6,482 & $230(3.4)$ \\
\hline ERHA $\left(\mathrm{PM}_{10}\right)$ & 51.50 & 49.80 & 1,663 & 1,607 & $56(3.4)$ \\
\hline EICDERV (CO) & 3.10 & 3.05 & 2,385 & 2,344 & $41(1.7)$ \\
\hline FETAL $\left(\mathrm{NO}_{2}\right)$ & 97.80 & 97.12 & 1,525 & 1,514 & $11(0.7)$ \\
\hline ETM $\left(\mathrm{PM}_{10}\right)$ & 51.50 & 49.80 & 9,176 & 8,867 & 309 (3.4) \\
\hline ERM $\left(\mathrm{PM}_{10}\right)$ & 51.50 & 49.80 & 2,487 & 2,402 & $85(3.4)$ \\
\hline ECVDM (CO) & 3.10 & 3.05 & 2,197 & 2,160 & $37(1.7)$ \\
\hline Total & & & & & 769 \\
\hline
\end{tabular}

$\mathrm{PM}_{10}$ : particulate matter; $\mathrm{NO}_{2}$ : nitrogen oxides; $\mathrm{CO}$ : carbon monoxide; $\mathrm{PRHA}$ : pediatric respiratory hospital admissions 16 ; ERHA: elderly respiratory hospital admissions 17; EICDERV: daily emergency room visits due to ischemic cardiovascular diseases 18; FETAL: late fetal deaths 19; ETM: all-cause elderly mortality 20; ERM: elderly respiratory disease mortality 21; ECVDM: elderly cardiovascular mortality 22.

* $\mathrm{PM}_{10}$ and $\mathrm{NO}_{2}: \mu \mathrm{g} / \mathrm{m}^{3} ; \mathrm{CO}: \mathrm{ppm}$;

** Compared to the basic (real) scenario.

Note: Pollutant concentrations in the blend scenario are lower than the real scenario because of the lower emissions resulting from the addition of ethanol and additive.

\section{Results}

\section{Impact evaluation}

The ethanol-blended diesel fuel consists of $91.8 \%$ common diesel, $7.7 \%$ ethanol, and $0.5 \%$ additive. The blend is less pollutant than common diesel and maintains the same engine performance. The blend would be prepared at the fuel distributors' sites, which would provide the final fuel to the users' fleet service stations.

\section{- Estimate of the diesel volume to be replaced by the ethanol/diesel/ additive blend}

Based on the established fleet scenario, this section estimates volumes $\left(\mathrm{m}^{3}\right)$ of decreased common diesel consumption, increased ethanol consumption and increased additive consumption.

The scenario for use of the additive in Greater Metropolitan São Paulo is: 180,789 trucks (50\% with additive), 42,528 buses (13,437 buses using common diesel only and 29,091 buses using the ethanol/diesel/additive blend, i.e., $70 \%$ of the bus fleet with the additive).

Considering the proportions of buses and trucks using the additive in the above scenario, we assumed an estimated $65 \%$ of total diesel consumption using additive, generating an increase in ethanol and additive consumption as follows:

\section{$\mathrm{Cdpf}=0.92 \times 0.65 \times \mathrm{Cdpi}$}

Where Cdpf = final consumption of common diesel after introduction of the additive (1.89 billion liters in the fleet with the additive) and Cdpi = consumption of common diesel before introduction of the additive ( 3.159 billion liters 5 ); $\mathrm{Cdpf}=0.35 \times \mathrm{Cdp}=1.11$ billion liters (in the fleet with common diesel only).

Analogously, consumption of ethanol (Caf) and additive (Cadit) would be: $\mathrm{Caf}=0.077 \times 0.65$ $\mathrm{x}$ Cdpi $=0.16$ billion liters $\geq 5 \%$ less than total common diesel used before introduction of the additive; Cadit $=0.005 \times 0.65 \times$ Cdpi $=0.01027$ billion liters.

\section{- Economic costs (identified)}

Some additional precautions are required in initial operations with the blend (Table 4).

\section{a) Cleaning of diesel storage tanks}

Diesel storage tanks in the fleets' internal service stations would have to be cleaned before introducing the supply with the additive, at an estimated cost of R\$350/tank (source: additive supplier).

This estimate was based on an assumed 1,000 tanks as the probable number needed to supply the bus and truck fleets that would use the additive under the scenario. 
Economic costs of additive implementation.

\begin{tabular}{lc}
\hline Costs & Quantitative (R\$) \\
\hline Cleaning of diesel storage tanks & 350,000 \\
Installation of vacuum and pressure valve in storage tank & 150,000 \\
Intensive training in safety and handling and periodic maintenance & 700,000 \\
Sub-total 1 & $1,200,000.00$ \\
Sub-total 2 (Additive cost + ethanol) X (diesel 100\% cost) & $70,156,800.00$ \\
Total (R\$) & $71,356,800.00$ \\
Total (US\$) & $24,437,260.27$ \\
\hline
\end{tabular}

\section{b) Installation of a vacuum and pressure valve in the storage tank}

The additive requires installing a vacuum and pressure valve in the storage tank. This procedure is quick, and only requires a tank stoppage time of a few hours. Estimated cost is R \$ 150/tank (source: additive supplier).

This estimate was also based on 1,000 tanks as the probable number needed to supply the bus and truck fleets.

\section{c) Intensive safety and operational training and periodic maintenance}

Before beginning operations with the additive, training (lasting about 4 hours) must be provided to mechanics, drivers, and employees who work with the fuel. The estimated cost is $\mathrm{R} \$ 1,000 /$ fleet of 50 vehicles (source: additive supplier).

Based on the number of metropolitan charter bus fleets (594), metropolitan regular bus fleets (50), and municipal systems (54), we estimated that 700 fleets (including trucks) would require such training.

\section{d) Additive cost+ethanol $x$ diesel $100 \%$ cost}

We considered average retail fuel prices in Greater Metropolitan São Paulo in 2002 6, as follows: (1) gasoline $\mathrm{C}(\mathrm{R} \$ / \mathrm{l})=1.688$; $(2)$ diesel $(\mathrm{R} \$ / \mathrm{l})=1.026$; (3) ethanol (hydrated) $(\mathrm{R} \$ / \mathrm{l})=0.911$; and (4) additive $(\mathrm{US} \$ / \mathrm{l})=3.5$ [source: additive supplier]. We used the average currency exchange rate for 2002 (US\$ $1.00=$ BR\$ 2.92) 7 .

Calculation of the values for supplying common diesel versus diesel with additive used $1 \mathrm{~m}^{3}$ (or 1,000 liters):

$1 \mathrm{~m}^{3}$ common diesel $=1,000 \times 1.026=$ $\mathrm{R} \$ 1.026$
$1 \mathrm{~m}^{3}$ diesel with additive (stabilized ethanol/ diesel blend) $=918 \times 1.026+77 \times 0.911+5 \times$ $(3.5 \times 2.92)=941.87+70.15+51.1=\mathrm{R} \$ 1,063.12$. This resulted in an additional cost (additive/common diesel) $=\mathrm{R} \$ 37.12 / \mathrm{m}^{3}$ or $3.6 \%$.

\section{- Economic benefits (identified)}

Use of the additive presents several advantages in motor maintenance and tank operation and supply. Although these benefits have already been shown, there are no quantitative measures of financial gains or time saving. The benefits described below were considered in qualitative terms in the final balance (Table 5).

Table 5

Economic benefits (identified)

\begin{tabular}{lcc}
\hline Benefits & Qualitative & Quantitative \\
\hline Additive's high lubricity & $\mathrm{XX}$ & $\mathrm{nq}$ \\
Dispersant detergent & $\mathrm{XX}$ & $\mathrm{nq}$ \\
Less contamination of lubricant oil & $\mathrm{XX}$ & $\mathrm{nq}$ \\
Identical engine performance & $\mathrm{ng}$ & $\mathrm{ng}$ \\
Total & All qualitative terms & \\
\hline
\end{tabular}

XX: estimated in qualitative terms; ng: negligible; nq: not quantified. 


\section{a) Additive's high lubricity}

The stabilized ethanol/diesel/additive blended fuel has high lubricity characteristics that provide better lubrication of vehicle engines and consequently longer oil drain intervals for motor maintenance as compared to common diesel.

\section{b) Dispersant detergent}

The additive's dispersant detergent characteristic reduces the engine residue, providing longer engine maintenance intervals and consequently lower operational costs.

\section{c) Less contamination of lubricant oil}

The additive has properties that cause less oil contamination, leading to longer oil drain intervals and thus generating measurable economic gains.

\section{d) Identical engine performance}

Fuel performance with the additive is identical to that with common diesel, i.e., there are neither advantages nor disadvantages in terms of fuel consumption per kilometer. This aspect is thus negligible.

\section{- Social and economic benefits (from sugarcane ethanol)}

Use of the additive requires the addition of ethanol, leading to an increase in sugarcane production (Table 6). Sugarcane is one of the most important crops in this sector of Brazil's economy, generating revenue and jobs for a large workforce during the harvest season. For this evaluation we adopted a short-term analysis, with the cane planted according to the traditional technique (burning of the field before manual harvesting), rather than the probable long-term adoption of mechanical harvesting (scheduled to be used in the State of São Paulo by 2012).

\section{a) Job generation (direct and indirect)}

The increase in ethanol consumption resulting from use of the additive would significantly impact São Paulo's socioeconomic structure due to generation of jobs.

The capacity of sugarcane cultivation to generate jobs is widely known, both quantitatively (number of workers needed for non-mechanical sugar can planting and harvesting) and qualitatively (unskilled labor, absorbing a population contingent that is usually excluded and normally has limited employment opportunities).

To estimate the number of jobs potentially generated by use of the additive, we used data from União da Indústria de Cana-de-Açucar (UNICA; the São Paulo's Sugarcane Agribusiness Association) 8 , considered the most up-to-date and representative data for this sector of the Brazilian economy.

The Brazilian sugarcane harvest in 20012002 totaled 281,042,145 tons of sugarcane and $11,560,652 \mathrm{~m}^{3}$ of total ethanol. Sugarcane occupies some 4.5 million hectares and produces 55\% ethanol and $45 \%$ sugar. The São Paulo State crop represents $60 \%$ and $61 \%$ of all the sugar and ethanol produced in Brazil, respectively.

Data on job generation from sugarcane cultivation in Brazil (2001) indicate approximately 610,000 direct jobs and 930,000 indirect and induced jobs.

Based on the above, estimated job generation due to use of the additive would produce an additional $55 \%$ of direct jobs $(335,500)+55 \%$ of indirect jobs $(511,500)$ due to an ethanol production of $11,560,652 \mathrm{~m}^{3}$ (additional production of 0.16 billion liters of ethanol $=160$ millions liters $=160,000 \mathrm{~m}^{3}$ ). 
Thus, use of the additive under the proposed scenario would generate 4,643 direct jobs and 7,079 indirect jobs.

Assuming a mean monthly wage of $\mathrm{R} \$ 520.00$ / sugarcane worker (about twice the national minimum wage), the additional annual revenue would be $\mathrm{R} \$ 73,148,538.68$ or US $\$ 25,050,869.41$.

\section{b) Permanent settlement and employment of an unskilled workforce}

The capacity to generate agricultural and industrial employment as a result of sugarcane is estimated at 1.5 million direct and indirect jobs. There are regional differences, and the job characteristics have evolved in the last ten years. The ethanol program has helped to reverse the rural exodus and to improve quality of life in various areas 9 .

To absorb a population contingent with limited employment opportunities and to maintain it in rural areas is a positive impact in itself, since rural exodus usually has a negative social impact, including slum formation (when the job opportunities that generated the migration cease or fail to materialize).

\section{c) Decreasing Brazil's energy dependence}

Reduction in the consumption of ordinary diesel due to partial replacement with the stabilized ethanol/diesel/additive blend is estimated at $5 \%$ of the initial volume required before introducing the new fuel. This impact would be positive because it would foster independence from diesel importation and favor the country's balance of payments.

\section{d) Sustainable development}

The sugarcane industry in Brazil is an example of important, large-scale sustainable energy production from biomass. The overall situation is now positive for most of the relevant sustainability issues, and the existing problems can be solved with available technology.

Economic sustainability has been achieved with sugarcane in Central and South Brazil, presenting the lowest production cost in the world and with the cost of ethanol lower than that of gasoline (and oil at US\$25/barrel). Sugarcane makes a major contribution to import substitution 9 .

The sugarcane industry has social advantages, which are essential for comparisons between ethanol and gasoline prices, even if one leaves them out of accounting analyses. e) Potential generation of carbon credits due to probable reduction in greenhouse gas emissions

The positive environmental externalities in the production and use of fuel alcohol and the need for developed countries to reduce $\mathrm{CO}_{2}$ emissions allow the sugarcane industry to request external funding for abating the emissions.

The energy balance developed by the Copersucar Technology Center (CTC) refers to the Brazilian 2002-2003 sugarcane crop, considering the analysis of the entire ethanol life cycle - from agricultural production to vehicle emissions - quantifying the environmental benefits of this renewable fuel as compared to petroleum. According to the study, each liter of ethanol generates a reduction of $0.71 \mathrm{~kg} /$ liter of carbon-equivalent in the atmosphere.

The IVU is linked to functional benefits such as microclimatic functions and carbon sequestration.

Based on Seroa-da-Motta et al. 10, US\$ 3.50 per ton of carbon represents the lowest estimated social cost of carbon emissions and US\$20.00 per ton of carbon the highest estimate. Multiplying the carbon sequestration capacity of sugarcane (agriculture and industry) from the additional ethanol $(158,127,977.71$ liters) to be used due to the implementation of the additive by the average social cost of US\$ 10.00 per ton of carbon, the result for carbon sequestration in sugarcane agriculture and industry is US $\$ 1,122,708$ per year.

\section{f) Environmental cost of sugarcane harvesting}

Sugarcane harvesting in Brazil is not mechanized and uses prior burning of the field before handcutting the cane. Burning is necessary to prevent workers from getting cut by the sharp cane straw and to avoiding venomous snakebites.

Arbex et al. 11 have shown the impacts of sugarcane burning in terms of air pollutant emissions, associated with increased hospital visits in the surrounding population. This impact could not be quantified in the final balance, since it would involve mapping all the cane harvest areas and the affected populations in the State of São Paulo.

\section{- Health costs and benefits due to the additive}

The additive's use would not jeopardize public health in any way. On the contrary, it would provide benefits, with a reduction in air pollutant 
levels (especially CO and $\mathrm{PM}_{10}$ ) in Greater Metropolitan São Paulo.

The projected health benefits would include a decrease in hospital admissions, emergency room visits, work absenteeism, and mortality.

Other benefits (not considered in the analysis) would include a decrease in expenses with medicines for patients not treated in hospitals and in the number of public and private medical consultations due to minor events related to discomfort caused by air pollutants, which the available studies do not estimate due to lack of official statistics.

Based on the evaluation of health gains (in terms of morbidity and mortality) in the results of the epidemiological analysis, two environmental valuations were estimated (Tables 7 and 8): one using U.S. Environmental Protection Agency (USEPA) 12 indicators and the other using data from the public health system 13 and the statistical value of life in São Paulo as defined by Seroada-Motta \& Mendes 14.

The valuation of DVU through ABM measures expenses with hospital admissions, loss of lives (through value of statistical life - VOSL) and work absenteeism related to the mean length of hospital stay associated with air pollution. Table 7 presents the econometric valuations. In the final assessment, valuation 2 was selected, since it adopts the local data (even if underestimated), instead of valuation 1 , which utilizes USEPA indicators.

\section{- Final balance}

In order to obtain an environmental cost-benefit analysis from use of the additive, the final balance considered all estimates of the preceding valuations (Table 9).

A conservative econometric evaluation was adopted, i.e., the lowest estimates obtained from the available indicators were always selected. The quantitative environmental cost-benefit analysis resulted in a positive balance of US\$ 2.851 billion.

Table 7

Health valuation estimates 1. U.S. Environmental Protection Agency data (US\$/1999).

\begin{tabular}{|c|c|c|c|c|c|c|c|c|}
\hline Outcomes & $\begin{array}{l}\text { Pollutants - } \\
\text { LAGS }\end{array}$ & $\begin{array}{c}\text { Avertable } \\
\text { events }(2000)\end{array}$ & $\begin{array}{l}\text { Hospital } \\
\text { admission } \\
\text { costs (US\$) }\end{array}$ & $\begin{array}{l}\text { Value of } \\
\text { statistical } \\
\text { life (VSL) }\end{array}$ & $\begin{array}{l}\text { Total costs } \\
\text { (US\$) }\end{array}$ & $\begin{array}{l}\text { Morbidity } \\
\text { costs (US\$) }\end{array}$ & $\begin{array}{c}\text { Mortality } \\
\text { costs (US\$) }\end{array}$ & $\begin{array}{c}\text { Total } \\
\text { morbidity+ } \\
\text { mortality (US\$) }\end{array}$ \\
\hline \multirow[t]{5}{*}{ PRHA } & $\begin{array}{l}\mathrm{PM}_{10} \\
\text { (7-day }\end{array}$ & & & & & & & \\
\hline & cumulative effect) & 230 & 830 & - & 191,068 & & & \\
\hline & $\mathrm{CO}$ & & & & & & & \\
\hline & (7-day & & & & & & & \\
\hline & cumulative effect) & 57 & $\mathrm{nq}$ & - & & & & \\
\hline ERHA & $\mathrm{PM}_{10}(\operatorname{lag} 0-1)$ & 56 & 830 & - & 46,365 & & & \\
\hline EICDERV & CO (lag0-1) & 41 & 1,142 & - & 47,391 & & & \\
\hline \multirow[t]{3}{*}{ FETAL } & $\mathrm{NO}^{2}$ & & & & & & & \\
\hline & (5-day & & & & & & & \\
\hline & moving average) & 11 & - & $\mathrm{ng}$ & & & & \\
\hline \multirow[t]{2}{*}{ ETM } & $\mathrm{PM}_{10}$ (lag 0-1) & 309 & - & 577,243 & $178,333,240$ & & & \\
\hline & CO (lag 0-1) & 95 & - & nq & & & & \\
\hline ERM & $\mathrm{PM}_{10}$ (lag 0-1) & 85 & - & nq & & & & \\
\hline ECVDM & CO (lag 0-1) & 37 & - & $\mathrm{nq}$ & & & & \\
\hline Total & & 923 & & & & $284,824,434$ & $178,333,239.62$ & $178,618,064.06$ \\
\hline
\end{tabular}

ng: negligible; nq: not quantified; PRHA: pediatric respiratory hospital admissions; ERHA: elderly respiratory hospital admissions; EICDERV: daily emergency room visits due to ischemic cardiovascular diseases; FETAL: late fetal deaths; ETM: all-cause elderly mortality; ERM: elderly respiratory disease mortality; ECVDM: elderly cardiovascular mortality.

Endpoint: US\$1,999. 
Health valuation estimates 2. Brazilian data ( $R$ /2003).

\begin{tabular}{|c|c|c|c|c|c|c|c|c|c|c|c|}
\hline $\begin{array}{l}\text { Out- } \\
\text { comes }\end{array}$ & $\begin{array}{c}\text { Pollutants - } \\
\text { LAGS }\end{array}$ & $\begin{array}{l}\text { Aver- } \\
\text { table } \\
\text { events } \\
(2000)\end{array}$ & $\begin{array}{c}\text { Hospital } \\
\text { admission } \\
\text { costs } \\
\text { (R\$/day) }\end{array}$ & $\begin{array}{l}\text { Aver- } \\
\text { age } \\
\text { number } \\
\text { of days }\end{array}$ & $\begin{array}{l}\text { Aver- } \\
\text { age } \\
\text { income } \\
\text { (R\$/day) }\end{array}$ & $\begin{array}{c}\text { Aver- } \\
\text { age } \\
\text { (days } \\
\text { absent } \\
\text { from } \\
\text { work) }\end{array}$ & $\begin{array}{l}\text { Value of } \\
\text { statistical } \\
\text { life } \\
\text { (VOSL) }\end{array}$ & $\begin{array}{c}\text { Total } \\
\text { costs (R\$) }\end{array}$ & $\begin{array}{l}\text { Morbidity } \\
\text { costs (R\$) }\end{array}$ & $\begin{array}{l}\text { Mortality } \\
\text { costs (R\$) }\end{array}$ & $\begin{array}{c}\text { Total } \\
\text { (absenteeism: } \\
\text { morbidity+ } \\
\text { mortality+ } \\
\text { days) }\end{array}$ \\
\hline \multirow[t]{2}{*}{ PRHA } & $\begin{array}{c}\mathrm{PM}_{10} \\
\text { (7-day } \\
\text { cumulative } \\
\text { effect) }\end{array}$ & 230 & 367.48 & 7 & 42.46 & $68,420.63$ & - & 592,162 & & & \\
\hline & $\begin{array}{c}\mathrm{CO} \\
\text { (7-day } \\
\text { cumulative } \\
\text { effect) }\end{array}$ & 57 & $\mathrm{nq}$ & nq & - & & & & & & \\
\hline ERHA & $\begin{array}{c}\mathrm{PM}_{10} \\
(\operatorname{lag} 0-1)\end{array}$ & 56 & 367.48 & 7 & 42.46 & $16,603.29$ & - & 143,697 & & & \\
\hline EICDERV & $\begin{array}{c}\mathrm{CO} \\
(\operatorname{lag} 0-1)\end{array}$ & 41 & 367.48 & 7 & 42.46 & $12,334.21$ & - & 106,749 & & & \\
\hline FETAL & $\begin{array}{c}\mathrm{NO}_{2} \\
\text { (5-day } \\
\text { moving } \\
\text { average) }\end{array}$ & 11 & - & & & & $\mathrm{ng}$ & & & & \\
\hline \multirow[t]{2}{*}{ ETM } & $\begin{array}{c}\mathrm{PM}_{10} \\
(\operatorname{lag} 0-1)\end{array}$ & 309 & - & & & & 7,714 & $2,383,160$ & & & \\
\hline & $\begin{array}{c}\mathrm{CO} \\
(\operatorname{lag} 0-1)\end{array}$ & 95 & - & & & & $\mathrm{nq}$ & & & & \\
\hline ERM & $\begin{array}{c}\mathrm{PM}_{10} \\
(\operatorname{lag} 0-1)\end{array}$ & 85 & - & & & & $\mathrm{nq}$ & & & & US\$1,114,625.51 \\
\hline ECVDM & $\begin{array}{c}\mathrm{CO} \\
(\operatorname{lag} 0-1)\end{array}$ & 37 & - & & & & $\mathrm{nq}$ & & & & \\
\hline Total & & 923 & & & & $28,937.50$ & & & $842,608.68$ & $2,383,160.32$ & $\mathrm{R} \$ 3,254,706.50$ \\
\hline
\end{tabular}

ng: negligible; nq: not quantified; PRHA: pediatric respiratory hospital admissions; ERHA: elderly respiratory hospital admissions; EICDERV: eaily emergency room visits due to ischemic cardiovascular diseases; FETAL: late fetal deaths; ETM: all-cause elderly mortality; ERM: elderly respiratory disease mortality; ECVDM: elderly cardiovascular mortality.

Number of events $x$ unit public costs (DATASUS 13 - average hospital admissions value).

Table 9

Summary of valuation estimates.

\begin{tabular}{lcc}
\hline Valuations & Qualitative & Quantitative \\
\hline Economic costs & - & $24,437,260.27$ \\
Economic benefits & $X X X$ & - \\
Social and economic benefits (sugar cane) & $X X X$ & $26,173,578.05$ \\
Health benefits & - & $1,114,625.51$ \\
Total & $\geq$ & $2,850,943.29$ \\
& & $B>>>C$
\end{tabular}

Values in US\$. 


\section{Discussion}

Partial replacement of common diesel with the stabilized ethanol/diesel/additive blend would improve the air quality in Greater Metropolitan São Paulo, mainly in relation to $\mathrm{PM}_{10}$, which can be evaluated in terms of health benefits (avertable events), carbon credits, and other social gains such as the generation of jobs due to increased sugarcane cultivation. All impacts of the additive's use were listed and evaluated. Some could be estimated in quantitative terms, while others were evaluated qualitatively. A quantitative environmental cost-benefit analysis resulted in a positive balance of US\$ 2.851 billion. Adding the qualitative benefits to this quantitative balance, the project's socioeconomic benefits far outweigh the measured environmental costs. The approach used here is common in environmental valuation studies 15 .

The study suggests that even a partial and small replacement of common diesel with the proposed blend would produce a major air quality improvement and thus important health benefits. The generation of jobs from sugarcane cultivation to produce ethanol may not represent an advantage in the near future in the State of São Paulo, since mechanical harvesting is scheduled for implementation in 2012, under a State ruling. Despite the social problem of unemployment (which could be mitigated by absorbing this workforce in other crops, like rubber plantations in the interior of São Paulo), the positive aspects of eliminating pre-harvest burning of sugarcane fields are expected to improve the air quality and thus the associated health and economic issues. Other benefits in this stage of the life cycle would include economic gains in the farm implement industry, carbon credits, job generation, tax revenue, and technological development (which can be expected to experience an increased demand). The balance should be monitored in the long term. However, the trend is for the balance to continue to be positive, since some qualitative benefits have still not been quantified, and additional benefits should be included, the most important of which involve health and environmental quality.

Greater Metropolitan São Paulo would definitely benefit from measures focusing on the replacement of diesel fuels with any form of biodiesel (ethanol or oilseed), which would produce quantitative and qualitative environmental, health, and socioeconomic gains, the three pillars of sustainability.

\section{Resumo}

A poluição atmosférica na Região Metropolitana de São Paulo, Brasil, é devida principalmente à queima de combustiveis fósseis utilizados no sistema de transportes. A fim de melhorar a qualidade do ar, são necessárias políticas e melhorias tecnológicas em combustíveis e motores veiculares. Neste sentido, foi realizada uma avaliação dos impactos ambientais e sociais da mistura estabilizada do uso de diesel/etanol na frota de ônibus e caminhões na Região Metropolitana de São Paulo. Essa avaliação mostrou reduções nos poluentes atmosféricos, especialmente o $M P_{10}$, o que contribuiu para um número de eventos de morbidade e mortalidade evitáveis estimados por meio de funções dose-resposta de estudos epidemiológicos em termos de doenças respiratórias e cardiovasculares. A valoração dos impactos representada através de uma análise custo-benefício ambiental resultou positiva em US\$2,851 milhões. Adicionando-se a essa quantia os benefícios estimados em termos qualitativos, pode-se concluir que os benefícios sócio-econômicos do projeto superam os custos mensurados. A Região Metropolitana de São Paulo se beneficiará de qualquer tipo de biodiesel produzindo ganhos em termos ambientais, de saúde e de inclusão sócio-econômica, os três pilares da sustentabilidade.

Impacto Ambiental; Emissões de Veículos; Poluentes do $\mathrm{Ar}$ 


\section{References}

1. Companhia de Tecnologia de Saneamento Ambiental. Relatório de qualidade do ar do Estado de São Paulo 2005. São Paulo: Companhia de Tecnologia de Saneamento Ambiental; 2006.

2. Seroa-da-Motta R. Manual para valoração de recursos ambientais. Brasília: Ministério do Meio Ambiente; 1998.

3. Tietenberg T. Environmental and Natural Resource Economics. New York: HarperCollins; 1997.

4. Kery-Smith V. Pricing what is priceless: a status report on non-market valuation of environmental resources. In: Folmer H, Tietenberg T, editors. The International Yearbook of Environmental and Resource Economics 1997/1998: a survey of current issues. Cheltenham: Edward Elgar; 1998. p. 156204.

5. Petrobras. Consumo de combustíveis nas capitais brasileiras. http://www2.petrobras.com.br/ portugues/index.asp (accessed on 12/Apr/2004).

6. Agência Nacional do Petróleo, Gás Natural e Biocombustíveis. Preços de combustíveis comercializados nos municípios. http://www.anp.gov.br (accessed on 05/May/2004).

7. Fundação Getúlio Vargas. Taxas de câmbio - série histórica. http://fgvdados.fgv.br (accessed on 08/ Jun/2004).

8. União da Indústria de Cana-de-Açúcar. O álcool e a geração de empregos. http://www.unica.com.br (accessed on 14/Apr/2004).

9. União da Indústria de Cana-de-Açúcar. Energia da cana de açúcar no Brasil. http://www.unica.com. br (accessed on 14/Apr/2004).

10. Seroa-da-Motta R, Mendonça MJC, Nepstad D, Diaz MCV, Alencar A, Gomes JC, et al. O custo econômico do fogo na Amazônia. Rio de Janeiro: Instituto de Pesquisa Econômica Aplicada; 2002. (Texto para Discussão, 912).

11. Arbex MA, Böhm GM, Conceição GMS, Saldiva PHN, Pope AC, Braga ALF. Assessment of the effects of sugar cane plantation burning on daily counts of inhalation therapy. J Air Waste Manage Assoc 2000; 50:1745-9.

12. U.S. Environmental Protection Agency. Evaluating the health benefits of air pollution reductions: recent developments at the USEPA. http:/ /www.epa. gov (accessed on 05/Apr/2004).
13. Departamento de Informática do SUS. Informações de saúde. http://www.datasus.gov.br (accessed on 25/Mar/2004).

14. Seroa-da-Motta R, Mendes AP. Custos de saúde associados à poluição do ar no Brasil. Pesquisa e Planejamento Econômico 1995; 25:165-98.

15. Mattos A, Mattos KMC. Valoração econômica do meio ambiente: uma abordagem teórica e prática. São Paulo: Rima Editora; 2004

16. Braga ALF, Saldiva PHN, Pereira LAA, Menezes JJC, Conceição GMS, Lin CA, et al. Health effects of air pollution exposure on children and adolescents in São Paulo, Brazil. Pediatr Pulmonol 2001; 31:10613.

17. Martins LC, Latorre MRDO, Saldiva PHN, Braga ALF. Air pollution and emergency room visits due to chronic lower respiratory diseases in the elderly: an ecological time-series study in Sao Paulo, Brazil. J Occup Environ Med 2002; 44:622-7.

18. Lin CA, Pereira LAA, Conceição GMS, Kishi HS, Milani Jr. R, Braga ALF, et al. Association between air pollution and ischemic cardiovascular emergency room visits. Environ Res 2003; 92:57-63.

19. Pereira LAA, Loomis D, Conceição GMS, Braga ALF, Arcas RM, Kishi HS, et al. Association between air pollution and intrauterine mortality in São Paulo, Brazil. Environ Health Perspect 1998; 106:325-9.

20. Saldiva PHN, Pope III CA, Schwartz J, Dockery DW, Lichtenfels AJFC, Salge JM, et al. Air pollution and mortality in elderly people: a time-series study in São Paulo, Brazil. Arch Environ Health 1995; 50:159-63.

21. Miraglia SGEK, Conceição GMS, Saldiva PHN, Strambi O. Analysis of the impact of fuel consumption on mortality rates in São Paulo. In: Sucharov L, Bidini G, editors. Urban transport and the environment for the 21st century. Southampton: Computational Mechanics Publications; 1997; p. 435-44.

22. Braga ALF, Pereira LAA, Miraglia SGEK, Conceição GMS, Saldiva PHN, Böhm GM. Integrated environmental strategies in the Metropolitan Region of São Paulo: the impact of PROCONVE on air pollution health effects in São Paulo: 1991-1994 and 19972000. http://www.epa.gov/ies/documents/brazil/ brazilfinalreport.pdf (accessed on 24/Abr/2005).

Submitted on $02 /$ May/2006

Final version resubmitted on 03/Apr/2007

Approved on 04/Apr/2007 